\title{
RAČUNALNA DINAMIKA FLUIDA I METODE VIZUALIZACIJE STRUJANJA FLUIDA
}

\section{COMPUTATIONAL FLUID DYNAMICS AND FLUID FLOW VISUALIZATION METHODS}

\author{
Elvis Žic ${ }^{*}$, Matija Pilat*
}

\begin{abstract}
Sažetak
$U$ ovom radu obrađena je tematika primjene i svrhe Računalne dinamike fluida (RDF) u svakodnevnoj praksi te metode vizualizacije strujanja fluida. Radi lakšeg shvaćanja pojma modela turbulencije u radu su navedene osnovne karakteristike fluida od kojih je fokus dan na viskoznosti i kompresibilnosti. U svrhu opisa dinamike gibanja fluida definirane su osnovne vladajuće jednadžbe strujanja fluida, koje uključuju laminarani i turbulentni režim toka. Značajan fokus ovog rada posvećen je kreiranju numeričkih modela primjenom Računalne dinamike fluida, od samog predprocesiranja, definiranja domene problema, izrade numeričke mreže, sve do parametara potrebnih za definiranje pojedinih turbulentnih modela te načina vizualizacije rješenja promatranog problema kroz postprocesiranje. Drugi dio rada razmatra eksperimentalne i računalne metode vizualizacije strujanja fluida unutar kojih su dani pojedini primjeri za svaku od metoda vizualizacije.
\end{abstract}

Ključne riječi: Računalna dinamika fluida, viskoznost, kompresibilnost, NavierStokesove jednadžbe, numeričko modeliranje, metode vizualizacije strujanja

\begin{abstract}
This paper deals with application and purpose of Computational Fluid Dynamics (CFD) in everyday practice and methods of fluid flow visualization. In order to facilitate the understanding of the concept of turbulence model the paper presents the basic characteristics of the fluid, of which the focus is on viscosity and compressibility. For the purpose of describing the dynamics of fluid motion, the basic governing equations of fluid flow are defined, which include laminar and
\end{abstract}

* Sveučilište u Rijeci, Građevinski fakultet, Radmile Matejčić 3, 51000 Rijeka E-mail: \{elvis.zic@uniri.hr, mpilat@student.uniri.hr\} 
turbulent flow regimes. A significant focus of this paper is given to the creation of numerical models using CFD, from preprocessing, defining the problem domain, creating a numerical network, to necessary parameters for defining individual turbulent models and methods of visualizing the solution of the observed problem through postprocessing. The second part of the paper discusses experimental and computational methods of fluid flow visualization, within which individual examples for each of the visualization methods are given.

Key words: Computational Fluid Dynamics, viscosity, compressibility, Navier-Stokes equations, numerical modeling, flow visualization methods

\section{Uvod}

Računalna dinamika fluida se $\mathrm{u}$ praksi koristi za rješavanje mnogobrojnih problema u raznim granama industrije i znanosti gdje se javljaju fluidi u gibanju [1,2]. Njena primjena u praksi daje smanjene troškove razvoja te omogućuje inženjerima da simuliraju različite uvjete koji su ili skupi ili izuzetno složeni za provedbu u laboratoriju. Prilikom analiziranja dinamike fluida potrebno je poznavati pojam strujnice i strujne cijevi, razliku između stacionarnog i nestacionarnog strujanja te laminarni i turbulentni tip strujanja. Važan pojam u sagledavanju vrtložnih strujanja vezan je za opis rotacije i cirkulacije čestica $[2,3,4]$ (Slika 1).

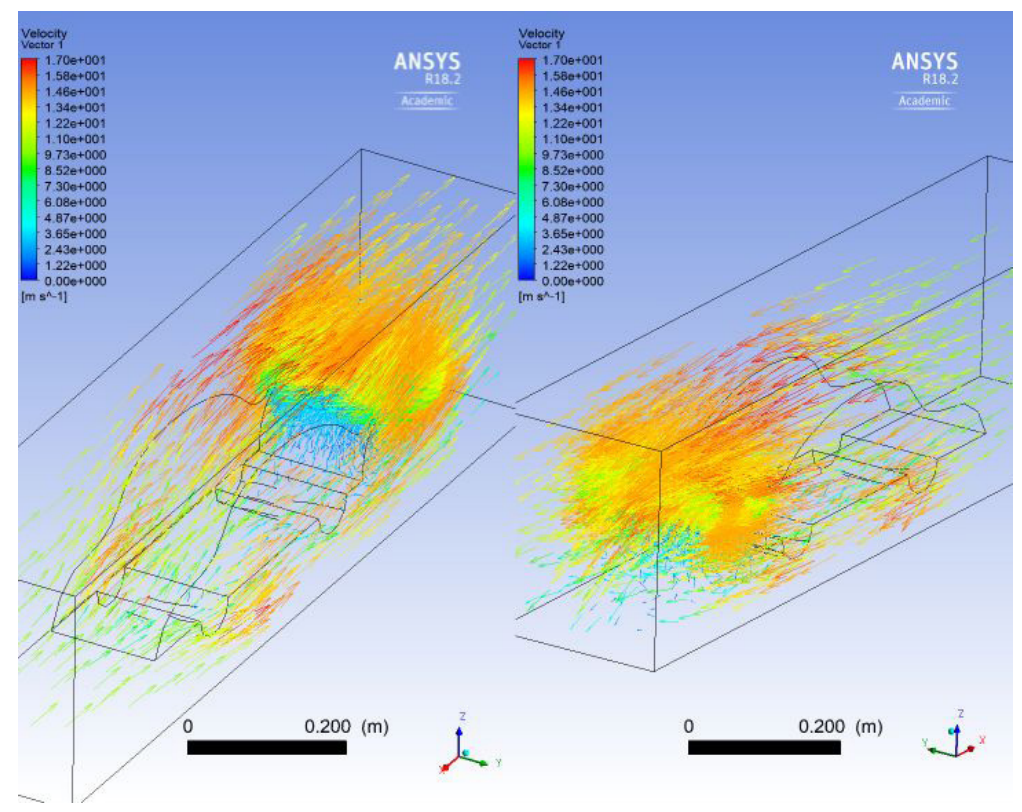

Slika 1. Prikaz vektora brzina opstrujavanjem zraka oko automobila; simulirano FLUENT računalnim programom [2] 
Računalna dinamika fluida $\mathrm{u}$ automobilskoj industriji uvelike se primjenjuje kod određivanja aerodinamičkog oblika auta (smanjenje otpora zraka), u aerodinamici kod formiranja adekvatnih oblika krila aviona (postizanje mjerodavnih sila uzgona, optimalizacija materijala za izgradnju krila i sl.), opstrujavanja kapljevine oko upornjaka mostova, na temelju čega se ispituju njegovi otpori oblika i otpori trenja) (Slika 1).

Korištenje numeričkih modela i računalnih potpomognutih metoda vizualizacije u Mehanici fluida ne znači da one mogu zamijeniti eksperimentalne metode [5,6]. U ovom radu su opisane faze koje se provode unutar numeričkih modela, kao i metode koje se koriste za diskretizaciju domene hidrotehničkih problema u praksi i rješavanje Navier-Stokesovih (NS) jednadžbi. Glavni fokus rada je prikaz metoda vizualizacije strujanja fluida, opisanih kroz eksperimentalne i računalno potpomognute metode.

\section{Osnovne karakteristike fluida}

S gledišta mehanike fluida, važna karakteristika fluida je njegova stlačivost ili kompresibilnost. Uslijed povećanja stlačivosti, kapljevina gotovo zadržava svoj izvorni volumen (pri pritisku od 600 bara kapljevina će se komprimirati za svega 1\%). Još jedna karakteristika kapljevine jest njena viskoznost, koja pokazuje otpornost uslijed njenog strujanja svaki puta kad dva sloja „kliznu“ jedan povrh drugog. Općenito, kapljevine su nekompresibilni (osim pri velikim tlakovima), a plinovi kompresibilni fluidi (može se zanemariti kod male promjene tlaka), [7,8]. Pojam viskoznosti se može vizualizirati na način da se opiše kapljevina koja ispunjava prazan prostor između dvije usko razmaknute paralelne ravne ploče površine $A$ i razmaka $h$ (donja je ploča fiksirana), a sila $F$ je potrebna da bi se gornja ploča paralelno pomicala brzinom $U$ (Slika 2). Dok je vrijednost $U h / v<$ $1500(v=\mu / \rho$, kinematička viskoznost kapljevine, $\mu$ - dinamička viskoznost kapljevine, $\rho$ - gustoća kapljevine) održava se laminarni tok i dobiva se

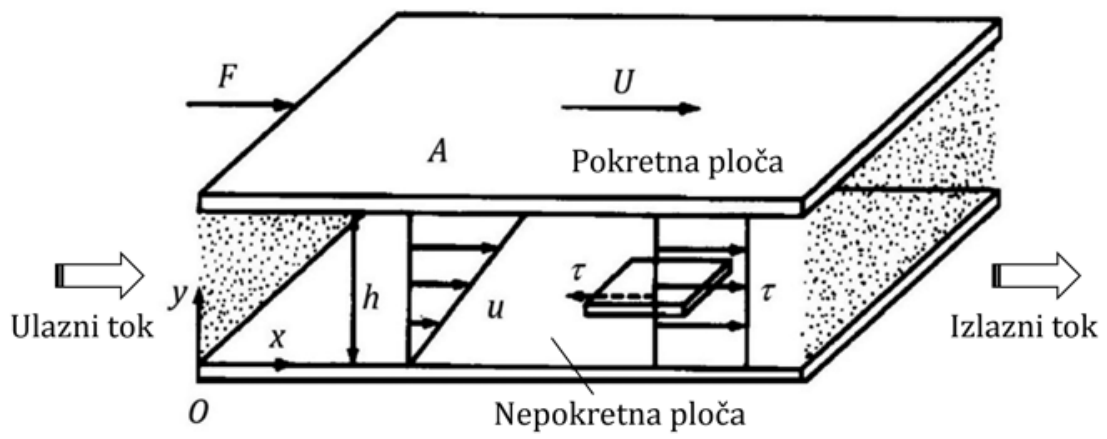

Slika 2. Prikaz Couettovog strujanja (modificirano prema [9]) 
linearna raspodjela brzine. Takav paralelni tok jednolikog gradijenta brzine naziva se Couetteovo strujanje [9]. U ovom je slučaju sila po jedinici površine potrebna za pomicanje ploče, tj. posmično naprezanje je proporcionalno brzini $U$ i obrnuto proporcionalno udaljenosti $h$. Pomoću proporcionalne konstante $\mu$, izraz se može zapisati na sljedeći način $[2,9]$ :

$$
\tau=\frac{F}{A}=\mu \frac{U}{h}
$$

Na Slici 2. prikazan je slučaj kada kapljevina u otvoru ne teče (giba se samo gornja ploča). U slučaju kada kapljevina teče, raspodjela brzine prikazana je na Slici 3. Proširenjem izraza (1), posmično naprezanje $\tau$ na dijelu $d y$, udaljenom za $y$ od čvrstog zida dano je sljedećom jednadžbom:

$$
\tau=\mu \frac{\mathrm{d} u}{\mathrm{~d} y}
$$

gdje omjer $d u / d y$ predstavlja gradijent brzine toka (brzina deformacije) po vertikali. Ovaj odnos je definirao Newton preko eksperimenta i nazvan je Newtonov zakon viskoznosti.

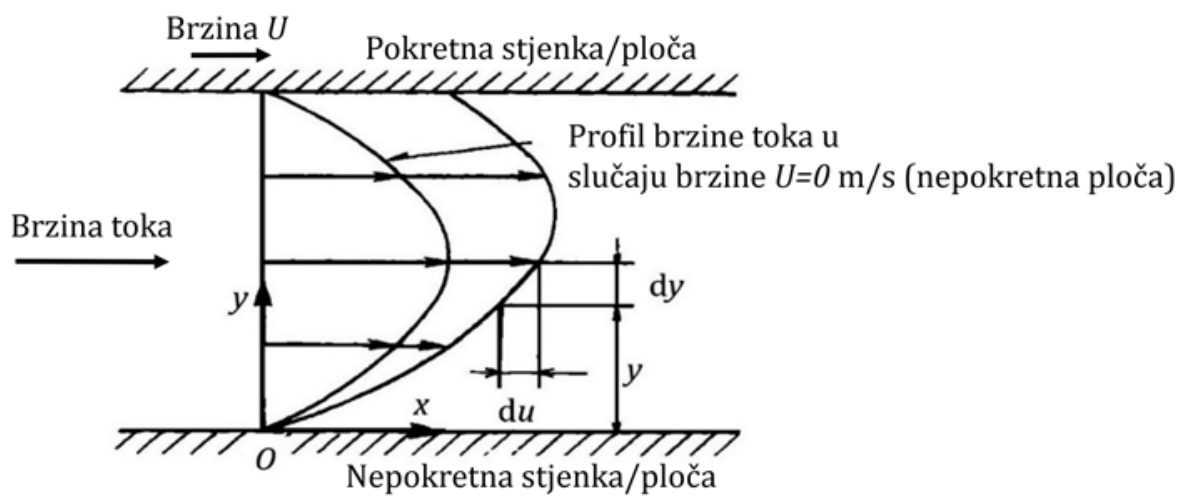

Slika 3. Strujanje kapljevine između dviju usporednih ploča (modificirano prema[9])

Prva posljedica viskoznosti fluida je otpornost na smicanje u skladu s Newtonovim zakonom viskoznosti (izraz (2)). Posmična viskoznost kod plinova s temperaturom raste, dok kod kapljevina opada $[1,8]$. Uz pretpostavku da je kapljevina volumena $V$ pri tlaku $p$ smanjila svoj volumen za $\Delta V$ zbog daljnjeg povećanja tlaka za $\Delta p$, zbog relativne promjene volumena kapljevine $\Delta V / V$, volumni modul stlačivosti $K$ jednak je [7]:

$$
K=\frac{\Delta p}{\Delta V / V}=-V \frac{d p}{d V}
$$

Recipročna vrijednost volumnog modula stlačivosti jest stlačivost $\beta$, čija vrijednost izravno ukazuje koliko je fluid kompresibilan. Stlačivost 
fluida je promjena volumena fluida pod učinkom promjene tlaka, za vodu pri normalnoj temperaturi i pritisku vrijednost $K=2,03^{*} 10^{9} \mathrm{~Pa}$, a za zrak $K=1,4 * 10^{5} \mathrm{~Pa}$, pretpostavljajući adijabatsku promjenu (termodinamički proces u kojem nema izmjene topline između sustava i okoline), [7]. U slučaju vode $\left(\beta=4,85^{*} 10^{-10} \mathrm{~Pa}^{-1}\right)$, njen se volumen smanjuje za samo 0,005 $\%$ čak i ako se atmosferski tlak poveća za $1 \mathrm{~atm}$. Volumni modul stlačivosti kapljevine određuje se iz brzine širenja zvuka u tekućini $(a=\sqrt{d p / d \rho}=$ $\sqrt{K / \rho})$.

\section{Temeljne osnove strujanja kapljevina}

Postoje dvije metode za proučavanje toka strujanja. Jedna je Lagrangeova metoda za opis gibanja kapljevine, koja slijedi proizvoljnu česticu s njezinim promjenama brzine i ubrzanja. Druga je Eulerova metoda, kojom se promjene brzine i tlaka, umjesto praćenja određene čestice fluida, proučavaju u fiksnim položajima u prostoru $x, y, z$ i u vremenu $t$. Danas je druga metoda u većini slučajeva češće primjenjivija i učinkovitija $[10,11]$.

Krivulja formirana vektorima brzine svake čestice fluida u određenom vremenu naziva se strujnica (linija toka). To je krivulja koju trenutni lokalni vektori brzine tangiraju u svakom trenutku. Ako se spoji veći broj strujnica u cjelinu, dobije se strujna cijev. Budući da je strujnica određena vektorima brzine, iz strujne cijevi ne dolazi do gubitaka kapljevine jer je ograničena rubnim strujnicama [12]. Ova je pretpostavka prikladna za proučavanje fluida u stacionarnom režimu toka.

Čestice fluida koje prolaze kroz uski prolaz kanala podvrgnute su deformaciji i rotaciji (Slika 4). Pretpostavlja se da se elementarni pravokutnik fluida ABCD sa stranicama $d x, d y$, koji se nalazi u središtu 0 , u trenutku $t$ pomiče na $0^{\prime}$, a pritom se kasnije deformira na $A^{\prime} B^{\prime} C^{\prime} D^{\prime}$ za vrijeme $d t$. Dužina AB u smjeru $x$ kreće se prema $A^{\prime} B^{\prime}$ dok se rotira za $d \varepsilon_{1}$, a $\mathrm{AD}$ u smjeru $y$ rotira se za $d \varepsilon_{2}$. Tada vrijede sljedeće jednakosti [7]:

$$
\begin{array}{ll}
d \varepsilon_{1}=\frac{\partial v}{\partial x} d x d t & d \varepsilon_{2}=-\frac{\partial u}{\partial y} d y d t \\
d \theta_{1}=\frac{d \varepsilon_{1}}{d x}=\frac{\partial v}{\partial x} d t & d \theta_{2}=\frac{d \varepsilon_{2}}{d y}=-\frac{\partial u}{\partial y} d t
\end{array}
$$

gdje $v / x$ predstavlja promjenu brzine po horizontali unutar vremena $d t$, dok $u / y$ predstavlja promjenu brzine po vertikali unutar vremena $d t$. Promjene nagiba kuta pravokutnika jesu $d \theta_{1}$ i $d \theta_{2}$. Kutne brzine od AB i AD su $\omega_{1}$ i $\omega_{2}$ te se mogu odrediti iz izraza:

$$
\omega_{1}=\frac{d \theta_{1}}{d t}=\frac{\partial v}{\partial x} \quad \omega_{2}=\frac{d \theta_{2}}{d t}=-\frac{\partial u}{\partial y}
$$


gdje je $d \theta_{1} / d t$ promjena nagiba kuta pravokutnika u vremenu $d t$. Za središte 0 , prosječna kutna brzina $\omega$ glasi:

$$
\omega=\frac{1}{2}\left(\omega_{1}+\omega_{2}\right)=\frac{1}{2}\left(\frac{\partial v}{\partial x}-\frac{\partial v}{\partial y}\right)
$$

Izraz iz zagrade u gornjoj jednadžbi daje ono što se naziva vrtlog oko $z$ osi:

$$
\zeta=\frac{\partial v}{\partial x}-\frac{\partial u}{\partial y}
$$

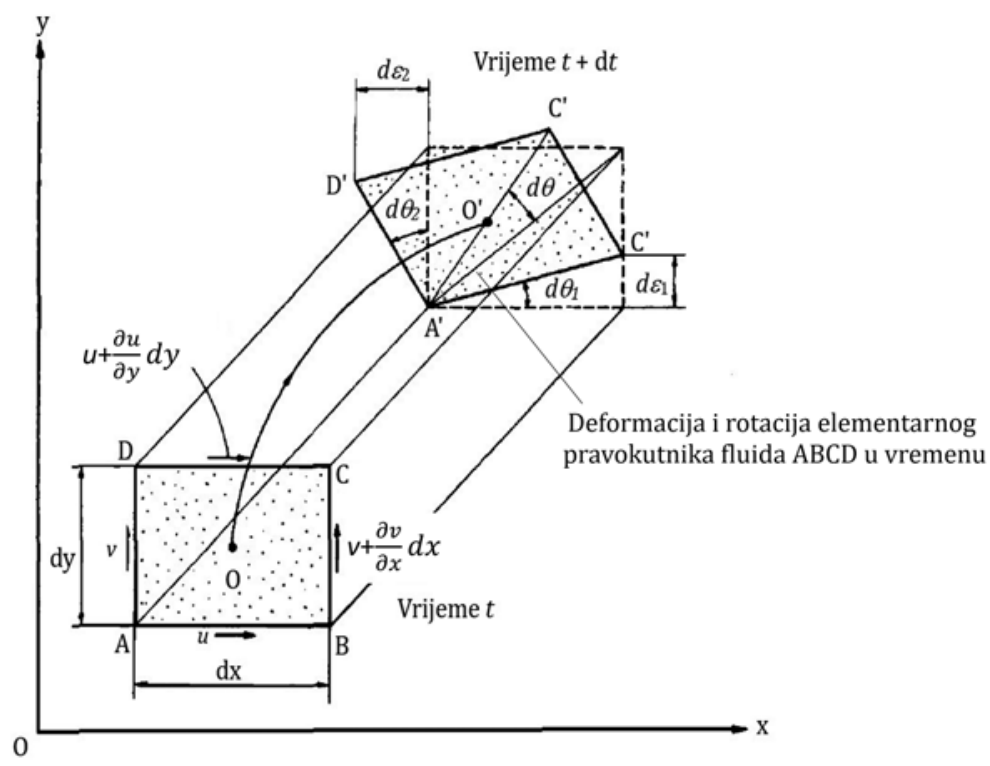

Slika 4. Deformacija elementarnog pravokutnika kapljevine (modificirano prema [7])

Ukoliko je izraz (8) jednak nuli tada, postoji i rotacijsko strujanje. Uragani, vrtložne vodene struje i tornado poznati su primjeri prirodnih vrtloga. Iako je struktura ovih vrtloga složena, osnovna struktura ima prisilni vrtlog u svom središtu i slobodni vrtlog na njegovom obodu [7]. Ako se pretpostavi zatvorena krivulja $s$ u $x y$ koordinatnom sustavu (Slika 5), tada integrirana brzina $v_{s}^{\prime}$ (komponenta brzine u tangencijalnom smjeru brzine $v_{s} \mathrm{u}$ određenoj točki na ovoj krivulji) duž te iste krivulje stvara cirkulaciju $\Gamma[7,8,12]$. U ovom se slučaju smjer rotacije suprotno od kazaljke sata uzima kao pozitivan. Kad se uzme da je kut između $v_{s}$ i $v_{s}^{\prime}$ jednak $\theta$, onda je cirkulacija određena preko izraza (9):

$$
\Gamma=\oint v_{s}^{\prime} d s=\oint v_{s} \cos \theta d s
$$


Područje okruženo zatvorenom krivuljom $s$ dijeli se u mikropodručja linijama paralelnim s osi $x$ i $y$ (Slika 5). Proučavajući cirkulaciju $\mathrm{d} \Gamma$ jednog takvog elementarnog pravokutnika ABCD (područje $\mathrm{d} A$ ) vrijedi [7]:

$$
\begin{aligned}
& d \Gamma=u d x+\left(v+\frac{\partial v}{\partial x} d x\right) d y-\left(u+\frac{\partial u}{\partial y} d y\right) d x-v d y=\left(\frac{\partial v}{\partial x}-\right. \\
& \left.\frac{\partial u}{\partial y}\right) d x d y=\zeta d x d y=\zeta d A
\end{aligned}
$$

pri čemu je $\zeta$ dva puta veća od kutne brzine $\omega$ rotacijskog strujanja (izraz (7)), a cirkulacija je jednaka proizvodu vrtložnosti po površini:

$$
\Gamma=\oint v_{s}^{\prime} d s=\oint_{A}^{\prime} \zeta d A
$$

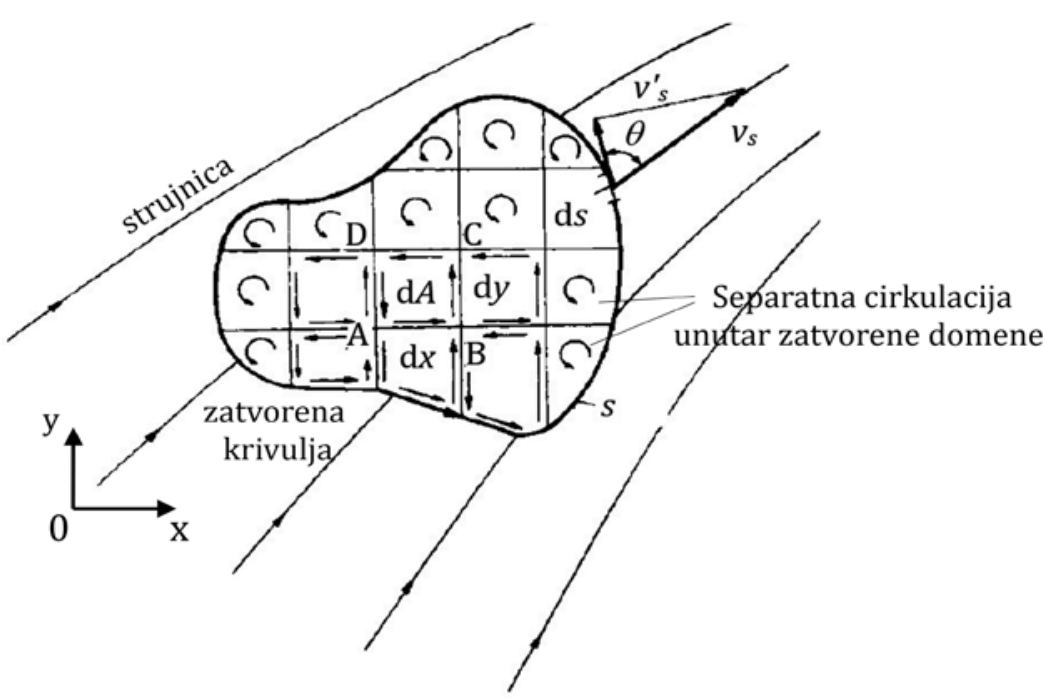

Slika 5. Prikaz cirkulacije u gibanju kapljevine (modificirano prema [7])

Iz jednadžbe proizlazi da je površinski integral vrtložnosti $\zeta$ jednak cirkulaciji, iz čega dalje proizlazi poznati Stokesov teorem [13,14]. Kada nema vrtloga unutar zatvorene krivulje, tada je cirkulacija oko njega jednaka nuli.

\section{Računalna dinamika fluida}

Računalna dinamika fluida (RDF) je grana znanosti koja predviđa (numerički modelira) strujanje fluida, prijenos topline i srodnih pojava pomoću numeričke simulacije. Tehnika je veoma značajna i obuhvaća široki raspon industrijskih i neindustrijskih područja primjene $[1,4]$. 
Rezultati RDF analize služe za detaljan razvoj proizvoda, rješavanje problema te za konceptualne studije novih dizajna i redizajna. One, u konačnici smanjuju ukupno uloženo vrijeme i napor koji je potreban u laboratoriju te daju praktički neograničenu razinu detalja o rezultatima. RDF kodovi strukturirani su oko numeričkih algoritama koji riješavaju problem strujanja fluida, a sadrže tri glavne faze: predprocesiranje (eng. Pre-processing), numerička rješenja i simulaciju (eng. Solver Execution) i postprocesiranje - rezultati i obrada podataka (eng. Post-processing), $[3,4,14]$.

Prvi korak rada je predprocesiranje, koje se sastoji od unošenja problema sa strujanjem $\mathrm{u}$ određeni RDF program pomoću sučelja prilagođenog operatoru i naknadne pretvorbe ovog ulaza u oblik pogodan za rješavanje numeričkih problema. Korisničke aktivnosti u fazi predprocesiranja uključuju definiranje početnih uvjeta i ciljeve modeliranja, definiranje domene koja će se dimenzionirati te konceptualnu izradu 2D ili 3D numeričke mreže. Rješenje problema strujanja u vidu pojedinih fizikalnih veličina (brzina, tlak, temperatura itd.) definirano je na čvorovima unutar svake ćelije. Točnost rješenja i njegova cijena, s obzirom na vrijeme izračuna i računalni hardver, ovise o finoći mreže.

Drugi korak u rješavanju problema strujanja fluida jest izbor i izvršavanje numeričkog rješenja gdje se postavlja numerički model. U numeričkim tehnikama rješenja postoji nekoliko različitih pristupa, od kojih se ovdje navode samo najpopularnije metode u praksi: metoda konačnih razlika, MKR (eng. Finite Difference Method), metoda konačnih volumena, MKV (eng. Finite Volume Method), metoda konačnih elemenata, MKE (eng. Finite Element Method) i metoda graničnih elemenata MGE (eng. Boundary Element Method), [5,15]. Metoda konačnih razlika je matematička metoda kojom se diferencijalni račun, koji se pojavljuje u vladajućoj jednadžbi, izravno aproksimira jednadžbama konačnih razlika. Međutim, u metodi konačnih elemenata [15], koristeći fizičke aproksimacije za diskretizaciju diferencijalnih jednadžbi, istovremeno se razvijaju algebarske jednadžbe za čitave elemente. Tako se dobiva približno rješenje diferencijalnih jednadžbi koje zadovoljavaju granične (rubne) uvjete. Područje strujanja u metodi konačnih razlika je podijeljeno u pravokutnu mrežu, dok se kod metode konačnih elemenata područje domene problema dijeli na trokutne, tetraedarske, heksagonalne ili hibridne elemente pravilnih ili nepravilnih oblika (kroz strukturirane i nestrukturirane mreže). Rubovi takvih elemenata nazivaju se čvornim točkama u kojima su definirane varijable. Za diskretizaciju metodom konačnih elemenata koristi se varijacijski princip ili metoda ponderiranih ostataka [7]. Metoda graničnih elemenata koristi integralnu jednadžbu koja mora zadovoljiti vrijednosti na granici. Za dobivanje integralne jednadžbe može se koristiti metoda korištenjem Greenove formule i metoda ponderiranih ostataka. 
Ova metoda se često uspoređuje s metodom konačnih elemenata i koristi se u mnogim područjima primjene [7,15]. U ovoj metodi je funkcija ponderiranja odabrana tako da zadovoljava Laplaceovu jednadžbu unutar određenog područja $S$ i pretvorena je u integralnu jednadžbu na granici. Granica se dijeli na niz elemenata linijskog segmenta, a zatim se vrijednost u određenoj točki elementa izražava u vrijednosti čvorne točke interpolacijskom jednadžbom u metodi konačnih elemenata. Tada se može riješiti istodobna linearna jednadžba za vrijednost u čvornim točkama.

Numerički algoritam se sastoji od tri koraka. Prvo se vrši integracija vladajućih jednadžbi strujanja fluida kroz sve (konačne) kontrolne volumene domene. Nakon toga slijedi diskretizacija - pretvorba rezultirajućih integralnih jednadžbi u sustav algebarskih jednadžbi. Zadnji korak algoritma numeričkih tehnika rješenja je rješavanje algebarskih jednadžbi nekom od direktnih metoda (Cramerovo pravilo, Gaussova eliminacija, LU razgradnja i sl.) ili iterativnih metoda (Jacobijeva metoda, Gauss-Seidelova metoda, SOR metoda i sl.) $[5,7,16]$.

Navier-Stokesove (NS) jednadžbe opisuju ponašanje Newtonovog fluida s promjenjivom gustoćom i viskoznošću. One su primjenjive na laminarne i turbulentne tokove kapljevina i plinova kroz cijeli raspon brzina toka. NS jednadžbe su izuzetno komplicirane i teško se rješavaju. Danas se one primjenjuju kod pojednostavljenja strujanja koja nas zanimaju budući da se mogu modelirati na način da se uzima konstantna gustoća i viskoznost fluida. Ne ulazeći u sve pojedinosti, jednadžba kontinuiteta i NS jednadžba za slučaj konstantne gustoće i konstantne viskoznosti može se napisati na sljedeći način [7]:

$$
\begin{aligned}
& \rho\left(\frac{\partial u}{\partial t}+u \frac{\partial u}{\partial x}+v \frac{\partial u}{\partial y}\right)=\rho f_{x}-\frac{\partial p}{\partial x}+\mu\left(\frac{\partial^{2} u}{\partial x^{2}}+\frac{\partial^{2} u}{\partial y^{2}}\right) \\
& \rho\left(\frac{\partial v}{\partial t}+u \frac{\partial v}{\partial x}+v \frac{\partial v}{\partial y}\right)=\rho f_{y}-\frac{\partial p}{\partial y}+\mu\left(\frac{\partial^{2} v}{\partial x^{2}}+\frac{\partial^{2} v}{\partial y^{2}}\right)
\end{aligned}
$$

Iz gornjeg izraza primjećuju se tri komponente ravnoteže sile koje djeluju na fluid. Ova ravnoteža se u vektorskom obliku zapisuje kao [8]:

$$
\rho \frac{D u}{D t}=\rho f-\nabla p+\mu \nabla^{2}
$$

U izrazu (13) mogu se prepoznati inercijske sile po jedinici volumena $\rho a=\rho(D u / D t)$, uravnotežene zbrojem sila koje djeluju na tijelo po jedinici volumena $\rho f$, tlačnim silama po jedinici volumena kao $-\nabla p$, i viskoznim silama po jedinici volumena $\mu \nabla^{2} u$. Pristupi rješavanju jednadžbi strujanja za turbulentno polje toka mogu se grubo podijeliti u dvije klase. Izravne numeričke simulacije (eng. Direct Numerical Simulation, DNS, [16]) koriste superračunala za numeričku integraciju NS jednadžbi, rješavajući sve prostorne i vremenske fluktuacije bez potrebe da se zasebno modelira 
proces turbulencije. DNS ostaje ograničen na vrlo jednostavne geometrije (npr. strujanje kanala, mlaznice i granični slojevi). Alternativa DNS-u, koja se nalazi u većini RDF paketa, jest rješavanje Reynoldsovih uprosječenih Navier-Stokesovih (RANS) jednadžbi (eng. Reynolds Averaged Navier-Stokes equations). RANS jednadžbe reguliraju srednju brzinu i tlak. Međutim, one zahtijevaju modeliranje turbulencije kako bi „zatvorili“ oscilirajući dio jednadžbe [3]. Valja napomenuti da se Reynoldsovo naprezanje najčešće modelira u smislu dva parametra turbulencije, turbulentne kinetičke energije $k$ i brzine rasipanja turbulentne energije $\varepsilon$ :

$$
\begin{gathered}
k \equiv \frac{1}{2}\left(\overline{u^{\prime 2}}+\overline{v^{\prime 2}}+\overline{w^{\prime 2}}\right) \\
\epsilon \equiv v\left[\left(\frac{\partial u^{\prime}}{\partial x}\right)^{2}+\left(\frac{\partial u^{\prime}}{\partial y}\right)^{2}+\left(\frac{\partial u^{\prime}}{\partial z}\right)^{2}+\left(\frac{\partial v^{\prime}}{\partial x}\right)^{2}+\left(\frac{\partial v^{\prime}}{\partial y}\right)^{2}+\left(\frac{\partial v^{\prime}}{\partial z}\right)^{2}+\right. \\
\left.+\left(\frac{\partial w^{\prime}}{\partial x}\right)^{2}+\left(\frac{\partial w^{\prime}}{\partial y}\right)^{2}+\left(\frac{\partial w^{\prime}}{\partial z}\right)^{2}\right]
\end{gathered}
$$

gdje je vektor fluktuirajuće brzine. Kinetička energija je jednaka nuli za laminarno strujanje i može biti velika do $5 \%$ kinetičke energije srednjeg toka u izrazito turbulentnom slučaju $[1,4,11]$. Familija modela općenito je poznata kao $k-\varepsilon$ i čini osnovu većine RDF paketa. U Tablici 1 navedeno je i opisano nekoliko različitih modela kojima se opisuje turbulencija u Ansys Fluent i CFX računalnim programima.

U proračunima temeljenim na uprosječenoj vremenskoj NS jednadžbi koristeći modele turbulencije, vrijeme je prosječno i promjena turbulencije tretira se kao glatka. Međutim, metoda kojom se pomoću računanja može pratiti promjena u nepravilnom mijenjanju turbulencije radi razjašnjenja fizičkih pojava je LES metoda (eng. Large Eddy Simulation Method) [3,4,14]. LES je metoda u kojoj se računanje vrši samo modeliranjem vrtloga koji su dovoljno mali da ostanu unutar mreže u smislu lokalne srednje vrijednosti, dok se veliki vrtlozi ne modeliraju, već izračunavaju onakvi kakvi jesu. Njezino glavno ograničenje je ogromna potrošnja računalnog vremena. Slika 6 prikazuje rezultate dobivene numeričkim LES modelom turbulencije strujanja oko cilindričnog upornjaka [2]. 
Tablica 1. Odabir i opis RANS modela turbulencije u Ansys Fluent i CFX računalnim programima, [2]

\begin{tabular}{|c|c|}
\hline Model & Opis i značajke: \\
\hline $\begin{array}{l}\text { Spalart-Allmaras } \\
\text { model }\end{array}$ & $\begin{array}{l}\text { Jednostavan model transportne jednadžbe koji izravno rješava } \\
\text { modificiranu turbulentnu viskoznost. Dizajniran posebno za } \\
\text { zrakoplovne primjene koje uključuju strujanja uz zid na finoj, } \\
\text { gotovo zidnoj prilagođenoj mreži. Implementacija omogućuje } \\
\text { upotrebu grubih mreža. Mogućnost uključivanja brzine } \\
\text { deformacije u } k \text { poboljšava predviđanja vrtložnih strujanja. }\end{array}$ \\
\hline $\begin{array}{l}\text { Standardni } k-\varepsilon \\
\text { model }\end{array}$ & $\begin{array}{l}\text { Bazično rješenje modela s dvije transportne jednadžbe za } k \text { i } \\
\varepsilon . \text { Koeficijenti su empirijski izvedeni; vrijedi samo za potpuno } \\
\text { turbulentne tokove. Primjena na viskozno grijanje, uzgon i } \\
\text { kompresibilnost, koji koriste druge } k-\varepsilon \text { modele. }\end{array}$ \\
\hline $\begin{array}{l}\text { RNG } k-\varepsilon \text { model } \\
\text { (renormalizacijska } \\
\text { grupna analiza NS } \\
\text { jednadžbi) }\end{array}$ & $\begin{array}{c}\text { Varijanta standardnog } k-\varepsilon \text { modela. Jednadžbe i koeficijenti su } \\
\text { analitički izvedeni. Značajne promjene u } \varepsilon \text { jednadžbi poboljšavaju } \\
\text { sposobnost modeliranja tokova s vrlo velikim naprezanjima. } \\
\text { Dodatne opcije pomažu u predviđanju vrtloženja i tokova kod } \\
\text { niskih vrijednosti Reynoldsovih brojeva } R e \text {. }\end{array}$ \\
\hline $\begin{array}{l}\text { Ostvarljiv } k-\varepsilon \\
\text { model }\end{array}$ & $\begin{array}{c}\text { Varijanta standardnog } k-\varepsilon \text { modela. Njegova „ostvarivost” proizlazi } \\
\text { iz promjena koje omogućuju poštivanje određenih matematičkih } \\
\text { ograničenja (poboljšane performanse modela). Ne smije se } \\
\text { koristiti zajedno s više okretnih referentnih okvira. }\end{array}$ \\
\hline $\begin{array}{l}\text { Standardni } k-\omega \\
\text { model }\end{array}$ & $\begin{array}{l}\text { Transportni model s dvije jednadžbe za rješavanje } k \text { i } \omega \text {, } \\
\text { specifična brzina disipacije }(\varepsilon / k) \text { temeljena na Wilcoxu (1998.) } \\
\text { [2]. Pokazuje vrhunske performanse za zidne turbulencije i } \\
\text { strujanja s niskim vrijednostima Re brojeva. Prikazuje potencijal za } \\
\text { predviđanje prijelaza. Mogućnosti obuhvaćaju prijelazna, slobodna } \\
\text { tangencijalna i kompresibilna strujanja. }\end{array}$ \\
\hline $\begin{array}{l}\text { SST } k \text { - } \omega \text { model } \\
\text { (Shear Stress } \\
\text { Transport } k-\omega \\
\text { model) }\end{array}$ & $\begin{array}{c}\text { Kombinira originalni Wilcoxov model (1988.) za uporabu u blizini } \\
\text { zidova i standardni } k \text { - } \varepsilon \text { model za proračun turbulencija dalje od } \\
\text { zida uporabom funkcije miješanja. Također ograničava turbulentnu } \\
\text { viskoznost kako bi se zajamčilo da je } \tau_{t} \sim k \text {. }\end{array}$ \\
\hline $\begin{array}{l}\text { RSM model } \\
\text { (Reynolds-Stress } \\
\text { Model) }\end{array}$ & $\begin{array}{c}\text { Reynoldsova naprezanja rješavaju se izravno jednadžbama } \\
\text { transporta kako bi se izbjegla pretpostavka izotropne viskoznosti } \\
\text { drugih modela. Koristi se za velika vrtložna strujanja. Kvadratna } \\
\text { opcija tlačnog opterećenja poboljšava performanse za mnoga } \\
\text { osnovna posmična strujanja. }\end{array}$ \\
\hline
\end{tabular}




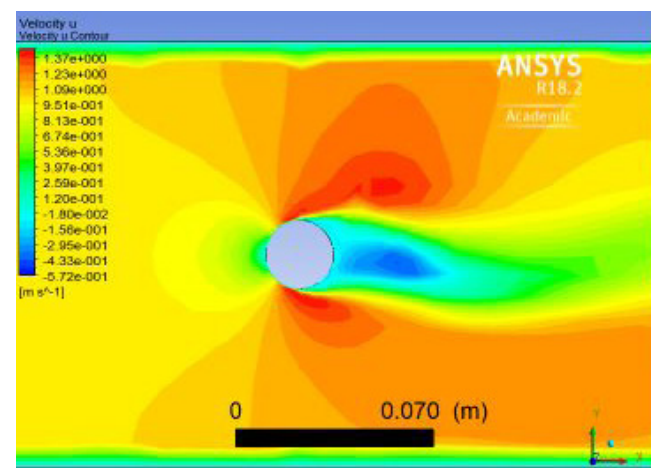

Slika 6. Turbulentno strujanje oko cilindričnog upornjaka [2]

Zadnja faza kod modeliranja fizikalnih procesa u Računalnoj dinamici fluida su rezultati i obrada podataka (eng. Post-processing). Mnogi RDF kodovi imaju implementirane izvanredne grafičke mogućnosti, a vodeći RDF paketi sada su opremljeni svestranim alatima za vizualizaciju podataka. Oni uključuju geometriju domene i prikaz mreže, vektorske prikaze, prikaz strujnica i zasjenjene konture, 2D i 3D površinske prikaze varijabilnosti pojedinih fizikalnih veličina, praćenje čestica u gibanju, manipulacijske prikaze (translacija, rotacija, skaliranje itd.), izlazne prikaze u boji (PostScript) i drugo. U novije vrijeme uključena je i animacija za dinamički prikaz rezultata, a svi kodovi proizvode pouzdane alfanumeričke izlaze i imaju mogućnosti izvoza podataka za daljnju manipulaciju izvan koda. Kao i u mnogim drugim granama Računalnog potpomognutog inženjerstva (eng. Computer-Aided Engineering, CAE), grafičke mogućnosti RDF kodova revolucionirale su komunikaciju ideja među korisnicima.

\section{Metode vizualizacije strujanja kapljevina}

Vizualizacija strujanja može se koristiti za razumijevanje i optimiziranje dizajna uređaja koji uključuju strujanja kapljevina i plinova. Golim okom je vidljivo strujanje vode, ali ne i strujnice ili raspodjela brzine. Konsolidirana znanost, koja analizira ponašanje fluida nevidljivog za oko te analizira hidrodinamička i aerodinamička strujanja u vidu konačnih slika, naziva se „vizualizacija strujanja“. Analitičkim istraživanjima, koja su pokušavala razjasniti dosadašnja nejasna strujanja i razvojna istraživanja strujanja u strojevima i oko njih, uvelike su od pomoći bile ove znanosti. Velika otkrića u području zakona sličnosti napravljena su vizualizacijom strujanja prije otprilike jednog stoljeća, a do njih je došao irski znanstvenik Osborne Reynolds [7]. U moderno vrijeme, napretkom superračunala, uporaba metode vizualizacije strujanja fluida poboljšana je obradom slika. Također, računalno potpomognuta vizualizacija strujanja (eng. Computer-Aided Flow 
Visualisation, CAFV), koja prikazuje slike numeričkih računanja i izmjerenih rezultata, bilježi veliki napredak $[5,12,14]$. Tehnike vizualizacije grubo su podijeljene na eksperimentalne metode i računalno potpomognute metode vizualizacije. U nastavku rada govorit će se nešto više o tim tehnikama.

\subsection{Eksperimentalne metode vizualizacije}

\subsubsection{Metoda trasiranja uz krutu stjenku (eng. Wall-tracing method)}

Metoda s uljnim filmom (eng. Oil-film method), tipična za ovu tehniku, odavno se koristi, pa je tehnika dobro uspostavljena (primjena kod strujanja fluida u blizini površine tijela ili zida i sl.). Na Slici 7.a) prikazan je tanak sloj ulja na površini lopatice Wellsove turbine za proizvodnju valova. Iz tog se uzorka može nadgledati priroda unutrašnjeg strujanja $[1,2,7]$.
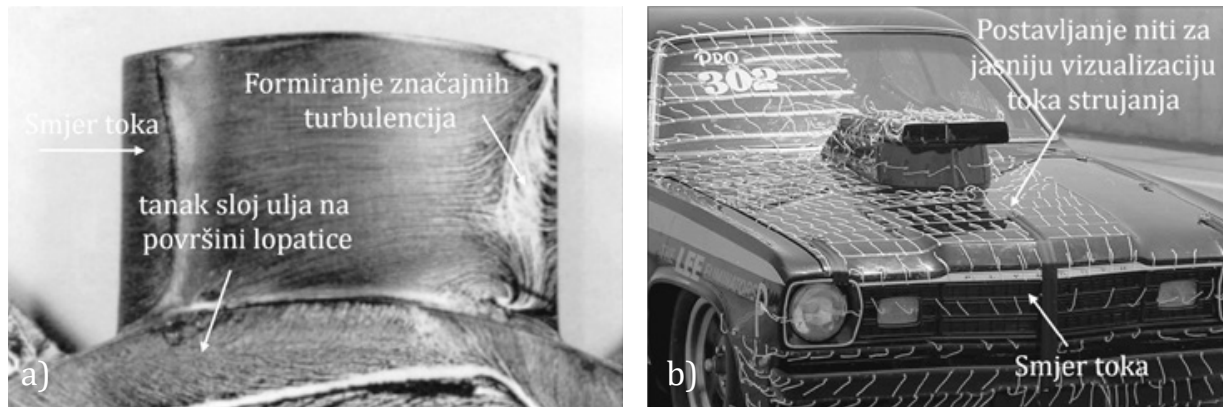

Slika 7. a) Ograničavanje strujnica Wellsove turbine za proizvodnju valova u vodi; brzina strujanja 3,2 $\mathrm{m} / \mathrm{s}$, kut strujanja fluida $11^{\circ}$, b) strujanje fluida oko automobila (površinska „nitna“ metoda), (modificirano prema [8])

\subsubsection{Površinska „nitna“ metoda (eng. „Tuft“ method)}

Iako je ovo neodređena metoda, koja se već neko vrijeme široko koristi za eksperimente s fluidima, nedavno je postala jednostavnija i informativnija jer su napravljeni detaljni eksperimenti i analize statičkih i dinamičkih karakteristika. Površinska metoda uz pomoć niti definira mali skup izduženih fleksibilnih izdanaka (niti) pričvršćenih ili zbijenih zajedno u bazi i slobodnih na suprotnim krajevima. Koristi se za vizualizaciju strujanja u blizini površina i oko površina zrakoplova, trupa i automobila, unutarnjih strujanja crpki i puhala i ventilacije u prostorijama, Slika 7.b).

\subsubsection{Metoda praćenja ubrizgavanjem (eng. Injection tracer method)}

Za strujanje vode već se dugo koristi metoda traga u boji. U metodi suspenzije koristi se aluminijski prah ili čestice polistirena, dok se u metodi praćenja površinskog gibanja koriste piljevina i aluminij. Postoji mnogo primjera za vizualizaciju strujanja oko ili iza krila aviona, trupa broda, 
automobila, zgrada i mostova, kao i za unutarnje strujanje cjevovoda, krvnih žila i pumpi $[7,8]$. Slika 8.a prikazuje strujanje fluida oko zrakoplova s dvostrukim delta krilom. Vizualizacija je sprovedena strujanjem vode te se na slici može vidjeti kako se razvijaju različiti vrtlozi. Ti vrtlozi djeluju na način da povećavaju uzgon potreban za dostizanje velikih brzina letjelica.
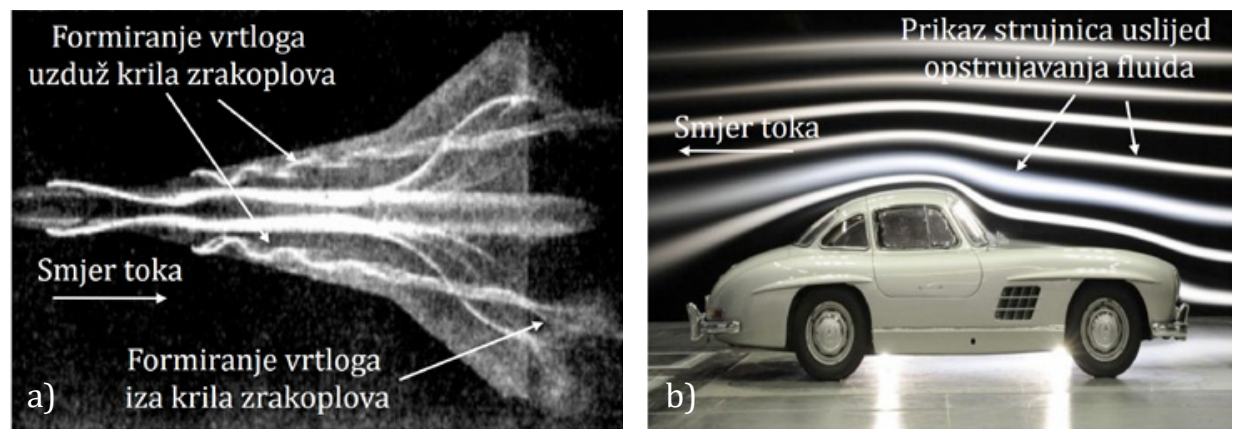

Slika 8. a) Strujanje fluida oko zrakoplova s dvostrukim delta krilom u vodi (metoda traga u boji), b) strujanje zraka oko automobila (metoda opstrujavanja zrakom),

(modificirano prema [8])

Slika 8.b prikazuje strujanje oko automobila koristeći metodu opstrujavanja zrakom. Ova metoda isključivo koristi zrak kao medij za opstrujavanje oko pojedinih tijela. Linije strujnica se jasno vide na slici.

\subsubsection{Metoda praćenja fluida primjenom kemijske reakcije (eng. Chemical reaction tracer method)}

Postoje razne tehnike i metode praćenja fluida pomoću kemijski reaktivnih tvari. Budući da imaju zanemarivu promjenu gustoće uslijed kemijske reakcije, brzina taloženja „tragača“ je mala, pa su mnogi od njih prikladni za vizualizaciju strujanja male brzine. Metoda se koristi za vizualizaciju strujanja fluida oko i iza ravne ploče, krila i trupa te kod strujanja unutar pumpe. Slika 9 prikazuje promatranje strujanja pomoću tragova razvijenih ubrizgavanjem zasićenog tekućeg amonijevog sulfida kroz finu cijev na smjesu bijelog olova i brzosušećeg ulja koje je naneseno na površinu modela jahte [8]. 


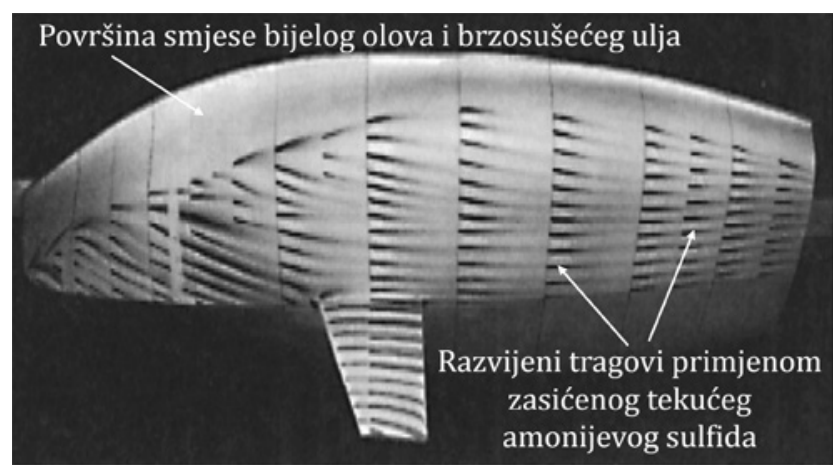

Slika 9. Strujanje na modelu jahte (metodom bojanja površinskog filma) u vodi;

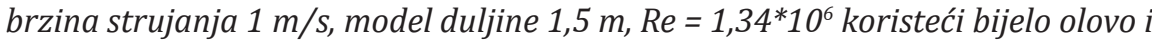
amonijev sulfid (modificirano prema [8])

\subsubsection{Električno kontrolirana metoda praćenja gibanja fluida (eng. Electrically controlled tracer method)}

U ovu su metodu uključene tri kategorije: metoda mjehurića vodika, metoda traženja iskre i tzv. metoda dimne žice (eng. Smoke-wire method). Bilo koja od njih sposobna je osigurati kvantitativno mjerenje. Pomoću ovih metoda moguće je opažanje strujanja fluida oko cilindra i formiranje vrtloga iza cilindra, strujanja fluida na ravnim pločama, sferama, krilima aviona, zrakoplova i trupa broda, strujanje u cilindru, strujanje oko ventila, kao i strujanje u kompresoru. Slika 10 prikazuje strujanje fluida oko krila aviona metodom traženja iskre (eng. Spark tracing method) [8].

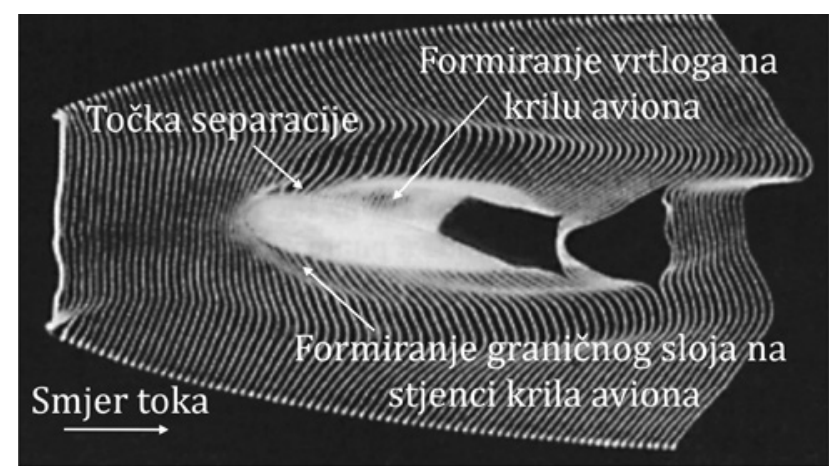

Slika 10. Strujanje fluida oko krila aviona u zraku; brzina strujanja $28 \mathrm{~m} / \mathrm{s}$, strujanje zraka pod kutom od $10^{\circ}, \operatorname{Re}=7,4^{*} 10^{4}$ (modificirano prema [8]) 


\subsubsection{Optička metoda vizualizacije (eng. Optical visualisation method)}

Ova se metoda široko koristi u praksi. Najznačajnija karakteristika ove metode jest sposobnost cjelovite vizualizacije bez utjecaja na strujanje fluida. Schlierenova metoda koristi promjenu brzine difrakcije uslijed promjene gustoće (temperature), Slika 11.

Interferencijska metoda, koja koristi činjenicu da je broj interferencijskih granica proporcionalna razlici gustoće, uglavnom se primjenjuje na strujanje zraka. Za strujanje vode slobodne površine koristi se stereofotografska metoda (eng. Stereophotography method). Neravnine na površini kapljevina se stereo fotografiraju (fotografska tehnika kojom se pomoću skupa 2D slika stvara 3D dojam) kako bi se utvrdila razlika u visini površine kapljevina i na taj način provjerilo stanje strujanja fluida. Moiré metoda ili metoda mramornog izgleda (eng. Moiré method) se također koristi za vizualizaciju strujanja vode. Stanje strujanja vode provjerava se dobivanjem kontura svijetlih i tamnih pruga koje ukazuju na neravnine na površini kapljevina $[8,12]$.

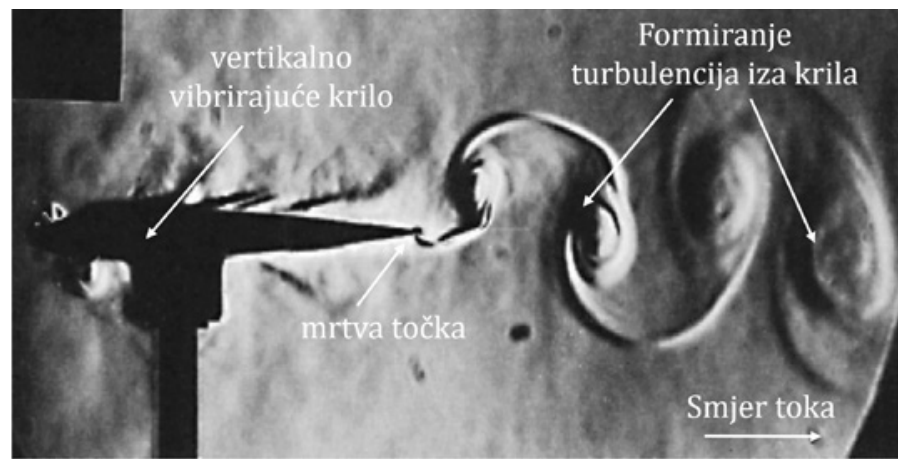

Slika 11. Strujanje fluida na dnu mrtve točke vertikalno vibrirajućeg krila (Schlierenova metoda) u zraku; brzina strujanja $5 \mathrm{~m} / \mathrm{s}$, duljina akorda $100 \mathrm{~mm}$, $R e=3^{*} 10^{4}$, vibracijska frekvencija $90 \mathrm{~Hz}$, jednostruka amplituda $4 \mathrm{~mm}$ (modificirano prema [8])

\subsection{Računalne metode vizualizacije}

\subsubsection{Metoda analize vizualizacijom slike (eng. Visualised image analysis} method)

U ovoj se metodi vizualizacija slike za potrebe buduće analize postavlja u statičnu fotografiju bez pokreta tako da se vrijednosti gustoća boja na slici digitaliziraju. Zatim se slika importira u računalo gdje će se analizirati analitički, statistički, u raspodjeli boja ili na neki drugi način, čime ju je i puno lakše protumačiti. Razvijene su različite tehnike za ovu metodu. Među 
njima je posebno popularna u zadnje vrijeme PIV metoda (eng. Particle Imaging Velocimetry Method). PIV metoda ili tehnika koristi se za dobivanje trenutnih mjerenja brzina i srodnih svojstava $u$ fluidu. U fluidu se nalaze čestice (koje se prethodno ubace u fluid) koje se prate te slijede dinamiku strujanja fluida. Fluid je osvijetljen tako da su čestice u njemu vidljive. Kretanje čestica koristi se za izračunavanje brzine i smjera strujanja koji se proučava. Slika 12.a prikazuje vektore brzine dobivene za strujanje kroz cilindar, prateći, s vremena na vrijeme, sferne plastične čestice koje su suspendirane u vodi [8]. Slika 12 .b je dobivena ubrizgavanjem i praćenjem plina (dima) s poda ispod stolice na kojoj je čovjek sjedio, a vizualizirana je prirodna konvekcija (razlika u temperaturi) oko ljudskog tijela.
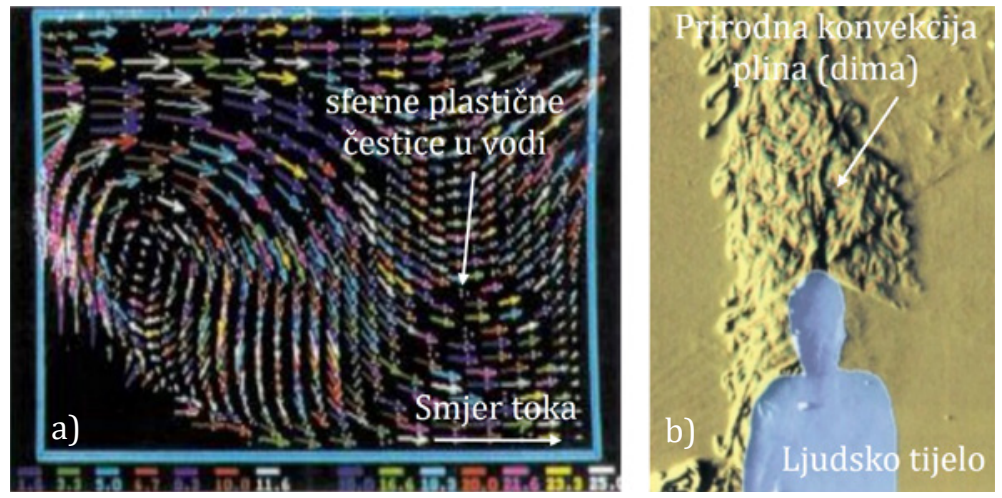

Slika 12. a) Vektori brzine strujanja kroz kružni cilindar u vodi (PTV metoda),

b) prirodna konvekcija temperature oko ljudskog tijela (metoda korelacije gustoće); brzina uzlazne mase $v_{\text {maks. }} \approx 0,2 \mathrm{~m} / \mathrm{s}$ (modificirano prema [8])

\subsubsection{Numerička metoda vizualizacije podataka (eng. Numerical data visualisation method)}

U ovoj metodi, polje strujanja se numerički analizira pomoću računala, a njegove izlazne vrijednosti (dobiveni rezultati) se lako predstavljaju razumljivom slikom pomoću računalne grafičke tehnike. Vrste prikaza uključuju: 1. konture (gdje su fizički jednake vrijednosti povezane krivuljom); 2. bojanje područja (obojena područja odgovaraju fizičkim količinama područja); 3. izopovršine (gdje se fizički jednake 3D vrijednosti očituju na površinama); 4. količinski prikaz (razine izražene u površinskim površinama očituju se promjenom stupnja transparentnosti) te 5 . vektorski (veličine i smjerovi brzine toka se prikazuju vektorima). Prezentacija (vizualni prikaz) može biti u vidu animacije ili grafova. Na slici 13.a dan je vizualni prikaz izveden trodimenzionalno. Konturni primjer obojenja područja (analiziranog objekta) prikazan je na Slici 13.b, uz prikaz raspodjele temperature [8]. 

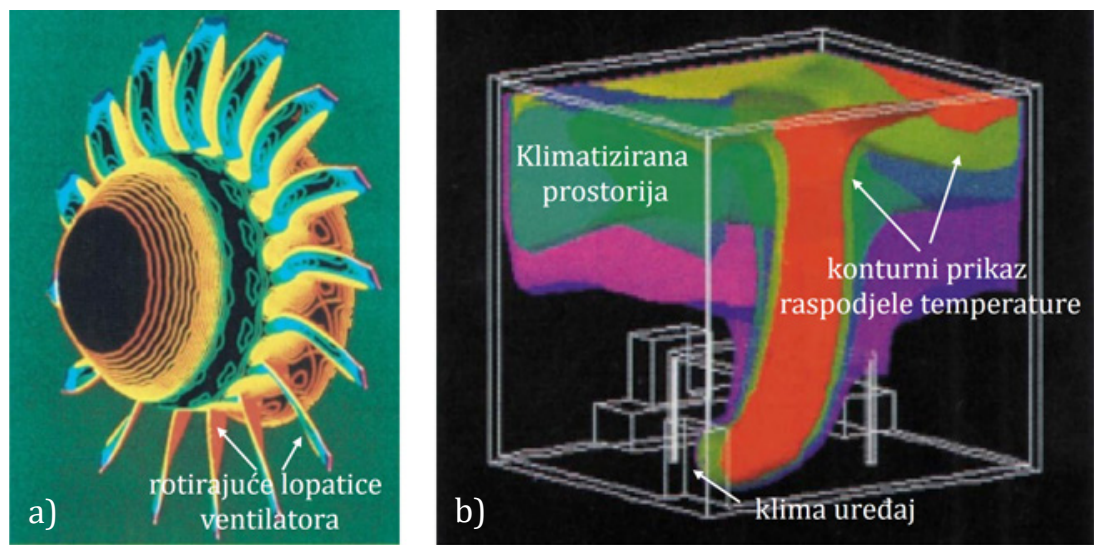

Slika 13. a) Raspodjela gustoće na rotirajućim lopaticama ventilatora i centrifuge; $D_{\text {vanjski }}=450 \mathrm{~mm}$, brzina rotacije $12700 \mathrm{o} / \mathrm{min}$ (plava boja: niska rotacija, crvena boja: visoka rotacija), $M K R, b$ ) raspodjela temperature u klimatiziranoj prostoriji (metoda manifestacije izopovršine), crvena boja prikazuje toplija područja (modificirano prema [8])

\subsubsection{Vizualizacija na temelju izmjerenih podataka (eng. Measured data visualisation method)}

Ako je polje strujanja izmjereno Pitotovom cijevi, anemometrom vruće žice, laserskim Doplerovim brzinomjerom, mjeračem tlaka, termometrom itd., takvi se rezultati mogu obraditi pomoću računala i na taj način se fizikalni procesi vizualiziraju kao slike. Na Slici 14, akustično strujanje žica iz violončela prikazano je metodom akustičkog intenziteta. Veličina i smjer energije strujanja u svakoj točki dobiva se računskim postupkom iz križnog vektora na temelju signala zvučnog tlaka na mikrofonu [8].

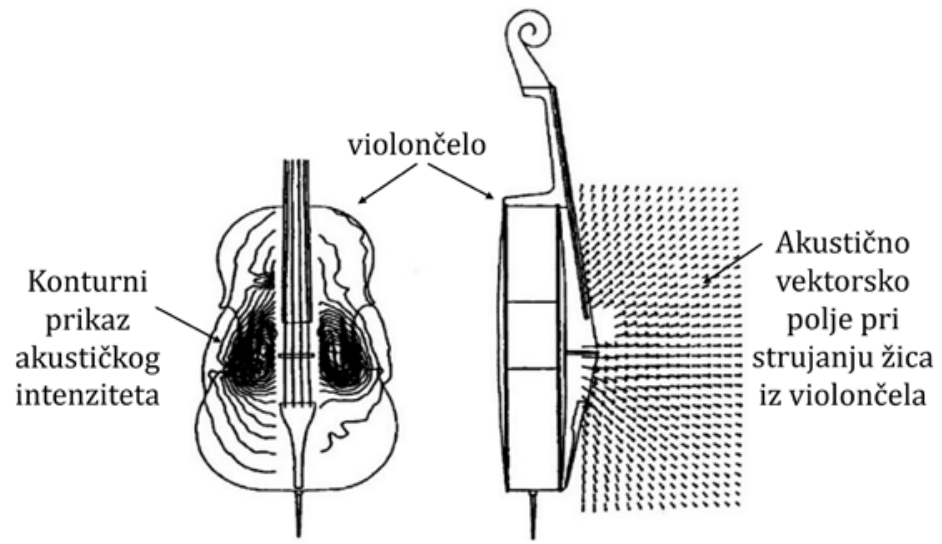

Slika 14. Strujanje zračenja fluida na violončelu (metoda zvučnog intenziteta), (modificirano prema [8]) 


\section{ZAKLJUČAK}

Postoji nekoliko jedinstvenih prednosti RDF-a u odnosu na pristupe dizajniranju fluidnih sustava, a koji se temelje na eksperimentima. Prije svega, to je značajno smanjenje vremena izvedbe i troškova novih dizajna, sposobnost proučavanja sustava u kojima je kontrolirane eksperimente teško ili nemoguće izvesti (npr. vrlo veliki sustavi), sposobnost proučavanja sustava pod opasnim uvjetima u granicama normalnih performansi i izvan njih (npr. sigurnosne studije i scenariji nesreća), kao i praktički neograničena razina detalja rezultata. RDF kodovi mogu proizvesti izuzetno velike količine rezultata uz relativno male troškove, a vrlo je jeftino izvoditi parametarske studije (npr. za optimizaciju performansi opreme). Preko $50 \%$ vremena provedenog u industriji na RDF projektu posvećeno je definiranju geometrije domene i stvaranju adekvatne mreže. Kako bi se maksimizirala produktivnost, svi glavni RDF kodovi za uvoz podataka iz vlastitih površinskih modela i generatora mreža kao što su PATRAN i I-DEAS sada uključuju vlastito sučelje u CAD okruženju. Svatko tko želi koristiti RDF na ozbiljan način mora shvatiti da on nije samo zamjena za eksperimentiranje, već vrlo moćan dodatni alat za rješavanje problema. Provjera valjanosti RDF koda zahtijeva vrlo detaljne informacije o graničnim uvjetima problema i generira veliku količinu rezultata. Da bismo ih valjano provjerili na smislen način, potrebno je izvesti eksperimentalne rezultate sličnog opsega (npr. laserskom Doppler anemometrijom ili PIV tehnologijom). Ukoliko fizikalni modeli za izvođenje eksperimentalnog rada ne postoje, korisnik RDF-a se mora osloniti na (i) prethodno iskustvo, (ii) usporedbe $s$ analitičkim rješenjima sličnih, ali jednostavnijih tokova i (iii) usporedbe s visokokvalitetnim podacima iz usko povezanih problema obrađenih u literaturi.

Vizualizacija strujanja može se postići fizikalnim eksperimentom (fizikalnim modeliranjem), analitičkim rješenjem ili računalnom simulacijom. Analiza slika generiranih tehnikama vizualizacije strujanja dovodi do vizualnog zapisa strujanja, koji inženjeri mogu koristiti kako bi poboljšali svoje razumijevanje fizikalnih procesa. Lagrangeov opis strujanja koristan je u vizualizaciji strujanja. Cjeloviti Lagrangeov opis sastoji se od poznavanja položaja svih čestica kapljevine u ovisnosti o vremenu, kao i svih dodatnih informacija potrebnih za utvrđivanje stanja svake čestice kapljevine u svakom trenutku.

Eksperimentalne tehnike i metode za prikaz strujanja fluida koriste se za pružanje informacija o stanju graničnog sloja na površini (npr. za otkrivanje točki separacije uslijed strujanja). Točniji način vizualizacije slobodnog strujanja jest uporaba dima ili laserskih listova. Čestice dima se kreću sa strujanjem i stoga daju određene naznake kako se strujanje fluida manifestira oko modela. Postprocesiranje unutar RDF-a uključuje stvaranje 
velikog skupa podataka koji predstavljaju realnu aproksimaciju stvarnog sustava. Pritom korisnik ima gotovo neograničen izbor razine detalja rezultata. Glavni ishod treba biti poboljšano razumijevanje ponašanja sustava, uz jasno provjeravanje točnosti simulacije. Ponovljena provjera valjanosti igra ključnu ulogu kao konačni mehanizam kontrole kvalitete. Međutim, glavni uspjeh u RDF-u su iskustvo i temeljito razumijevanje fizike strujanja fluida i osnova numeričkih algoritama. Bez njih je vrlo malo vjerojatno da će korisnik izvući najbolje iz numeričkog koda.

Zahvala. Ovaj je članak rezultat rada u okviru projekta Razvoj istraživačke infrastrukture na kampusu Sveučilišta u Rijeci (RC.2.2.060001) koji je sufinanciran iz Europskog fonda za regionalni razvoj (EFRR) $i$ Ministarstva znanosti, obrazovanja i sporta Republike Hrvatske.

\section{Literatura}

[1] Versteeg, H.K., Malalasekera, W. (2007) An Introduction to Computional Fluid Dynamics, Pearson Education Limited.

[2] Žic, E. (2019) Materijali sa 3. ljetne škole pod nazivom „3rd Summer School of Computational Fluid Dynamics, CFD“, Fakultet tehničkih nauka, Sveučilište u Novom Sadu, Novi Sad, 5-10.7.2019.

[3] Fletcher, C.A.J. (1991) Computational Techniques for Fluid Dynamics, Vols I and II, Springer-Verlag, Berlin.

[4] Abbott, M.B., Basco, D.R. (1989) Computational Fluid Dynamics - An Introduction for Engineers, Longman Scientific \& Technical, Harlow.

[5] Roache, P.J. (1976) Computational Fluid Dynamics, Hermosa, Albuquerque, NM.

[6] Thomson, J.F. (1984) Grid Generation Techniques in Computational Fluid Dynamics, AIAA J., Vol. 22, No. 11, pp. 1505-1523.

[7] Shaughnessy, E.J., Katz, I.M., Schaffer, J.P. (2005) Introduction to Fluid Mechanics, Oxford University, Oxford.

[8] Nakayama, Y., Boucher, R.F. (1999) Introduction to Fluid Mechanics, Butterworh-Heinemann, Oxford.

[9] Pilat, M. (2020) Računalna dinamika fluida i metode vizualizacije strujanja tekućine, Završni rad iz kolegija Hidromehanika, Građevinski fakultet Rijeka, Rijeka, 70 str.

[10] Bird, R.B., Stewart, W.E., Lightfoot, E.N. (2002) Transport Phenomena, 2nd edn., John Wiley \& Sons, New York.

[11] Ferziger, J.H., Perić, M. (2001) Computational Methods for Fluid Dynamics, 3rd rev. edn., Springer-Verlag, New York.

[12] Nakayama, Y. (1988) Visualised Flow, Pergamon Press, Oxford.

[13] White, F.M. (1991) Viscous Fluid Flow, 2nd edn., McGraw-Hill, New York. 
[14] Wilcox, D.C. (1993) Turbulence Modelling for CFD, DCW Industries Inc., La Canada, CA.

[15] Zienkiewicz, O.C., Taylor, R.L. (1991) The Finite Element Method - Vol. 2: Solid and Fluid Mechanics, McGraw-Hill, New York.

[16] Kasagi, N. (1998) Progress in Direct Numerical Simulation of Turbulent Transport and Its Control, Int. J. Heat Fluid Flow, Vol. 19, pp. 125-134. 
